\title{
Article
}

\section{Prevalence and Characterization of PVL-Positive Staphylococcus aureus Isolated from Raw Cow's Milk}

\author{
Asmaa Sadat ${ }^{1}{ }^{(}$, Radwa Reda Shata $^{2}$, Alshimaa M. M. Farag ${ }^{3}$, Hazem Ramadan ${ }^{4} \mathbb{D}$, Adel Alkhedaide ${ }^{5}$, \\ Mohamed Mohamed Soliman ${ }^{5}\left(\mathbb{D}\right.$, Mohamed Elbadawy ${ }^{6}(\mathbb{D}$, Amira Abugomaa $7, *(1)$ and Amal Awad $1, * \mathbb{C}$
}

check for

updates

Citation: Sadat, A.; Shata, R.R.; Farag, A.M.M.; Ramadan, H.; Alkhedaide, A.; Soliman, M.M.; Elbadawy, M.; Abugomaa, A.; Awad, A. Prevalence and Characterization of PVL-Positive Staphylococcus aureus Isolated from Raw Cow's Milk. Toxins 2022, 14, 97. https://doi.org/10.3390/ toxins14020097

Received: 21 December 2021

Accepted: 21 January 2022

Published: 25 January 2022

Publisher's Note: MDPI stays neutral with regard to jurisdictional claims in published maps and institutional affiliations.

Copyright: (C) 2022 by the authors. Licensee MDPI, Basel, Switzerland. This article is an open access article distributed under the terms and conditions of the Creative Commons Attribution (CC BY) license (https:// creativecommons.org/licenses/by/ $4.0 /)$.
1 Department of Bacteriology, Mycology, and Immunology, Faculty of Veterinary Medicine, Mansoura University, Mansoura 35516, Egypt; asmaasadat@mans.edu.eg

2 Department of Food Hygiene and Control, Faculty of Veterinary Medicine, Mansoura University, Mansoura 35516, Egypt; radwa.reda@yahoo.com

3 Department of Internal Medicine and Infectious Diseases, Faculty of Veterinary Medicine, Mansoura University, Mansoura 35516, Egypt; dr_alshimaafarag@mans.edu.eg

4 Hygiene and Zoonoses Department, Faculty of Veterinary Medicine, Mansoura University, Mansoura 35516, Egypt; hazem_hassan@mans.edu.eg

5 Clinical Laboratory Sciences Department, Turabah University College, Taif University, Taif 21995, Saudi Arabia; a.khedaide@tu.edu.sa (A.A.); mmsoliman@tu.edu.sa (M.M.S.)

6 Department of Pharmacology, Faculty of Veterinary Medicine, Benha University, Moshtohor, Toukh 13736, Elqaliobiya, Egypt; Mohamed.elbadawy@fvtm.bu.edu.eg

7 Faculty of Veterinary Medicine, Mansoura University, Mansoura 35516, Egypt

* Correspondence: s193249s@st.go.tuat.ac.jp (A.A.); amalabdo@mans.edu.eg (A.A.)

\begin{abstract}
The present study aimed to investigate the prevalence, antibiotic susceptibility profiles, and some toxin genes of Panton-Valentine leukocidin (PVL)-positive Staphylococcus aureus (S. aureus) in unpasteurized raw cow's milk collected from retail outlets located at Mansoura, Dakahliya governorate, Egypt. In that context, a total of 700 raw cow's milk samples were investigated for the presence of $S$. aureus, which was identified in $41.1 \%$ (288/700) of the samples. Among the S. aureus isolates, 113 PVL-positive $S$. aureus were identified and subjected for further analysis. The PVLpositive $S$. aureus were investigated for the existence of toxin-related genes, including hemolysin (hla), toxic shock syndrome toxin-1 (tst), and enterotoxins (sea, seb, sec, see, seg, sei, and selj). Genotypic resistance of PVL-positive strains was performed for the detection of blaZ and mecA genes. Among the PVL-positive S. aureus, sea, seb, and sec were detected in $44.2,6.2 \%$, and $0.9 \%$, respectively, while the $h l a$ and tst genes were identified in $54.9 \%$ and $0.9 \%$, respectively. The blaZ and mecA genes were successfully identified in $84.9(96 / 113)$ and $32.7 \%$ (37/113) of the total evaluated S. aureus isolates, respectively. PVL-positive $S$. aureus displayed a high level of resistance to penicillin, ampicillin, and trimethoprim-sulfamethoxazole. Multidrug resistance (resistant to $\geq 3$ antimicrobial classes) was displayed by all methicillin-resistant $S$. aureus (MRSA) and $38.2 \%$ of methicillin-sensitive $S$. aureus (MSSA) isolates. The obtained findings are raising the alarm of virulent PVL-positive MRSA clones in retail milk in Egypt, suggesting the requirement for limiting the use of $\beta$-lactam drugs in foodproducing animals and the importance of implementing strong hygiene procedures in dairy farms and processing plants.
\end{abstract}

Keywords: Staphylococcus aureus; pvl gene; MRSA; antimicrobial resistance; enterotoxins

Key Contribution: Some isolated PVL-positive S. aureus from raw cow's milk expressed various toxin- and bacterial-resistance-related genes and displayed a high level of resistance to several antibacterials. Multidrug-resistance (resistant to $\geq 3$ antibacterials) was also displayed by all MRSA and some MSSA isolates. 


\section{Introduction}

Milk and dairy products are significant sources of macro-and micro-nutrients required by humans, making them vulnerable to microbial pathogen contamination. The ingestion of contaminated raw milk is the major cause of serious food-poisoning outbreaks, potentially resulting from microbial toxin production [1]. Contaminated raw milk may contain hazardous microorganisms that cause milk to spoil or the onset of public health hazards [2]. Staphylococcus aureus (S. aureus) is one of the most important opportunistic pathogens of raw milk that can cause serious infection in humans [3].

Staphylococcus aureus has high pathogenicity due to its widespread distribution, high contamination rate, and rapid transmission. It can cause a wide range of clinical symptoms, from minor superficial skin lesions to significant invasive infections, and it can even be life-threatening [4]. However, S. aureus can enter milk through direct excretion from the udder of a cow with clinical or subclinical staphylococcal mastitis, as well as through contamination from the environment during raw milk handling and processing, posing a risk to consumers [5]. Therefore, it is critical to monitor virulent strains of S. aureus regularly to detect the potential risk this bacterium poses to public health [6].

The severity of the clinical signs and infections caused by $S$. aureus are linked to the presence of virulence factors. Among them, extracellular toxins, including staphylococcal enterotoxins (SEs), toxic-shock syndrome toxin-1 (TSST-1), staphylococcal hemolysins, and Panton-Valentine leukocidin (PVL) [7-9]. These toxins are the cause of food poisoning and many other clinical manifestations affecting humans and animals. Staphylococcal enterotoxins (SEs) are thermostable toxins that cause enterotoxaemia due to the consumption of food contaminated with enterotoxigenic strains [10]. Staphylococcal enterotoxins (SEs) act as superantigens that trigger the expression of the $I L-4$ and $I L-10$ genes, followed by the activation of TH2 cells. As a result, the clearance of invading infections is suppressed [11]. Many SEs have been discovered, and classical enterotoxins are divided into five serological types: SEA, SEB, SEC, SED, and SEE [12]. The traditional enterotoxin genes have been responsible for $90 \%$ of food poisoning outbreaks [13]. Among the Staphylococcus virulence factors, toxic shock syndrome toxin TSST-1 is a superantigenic and powerful toxin that causes toxic shock syndrome, which is characterized by many clinical signs, multi-organ dysfunction, and, finally, death. TSST-1 activates T cells in a nonspecific manner, resulting in an excessive immune response and excessive cytokine production [14]. Additionally, S. aureus produces alpha, beta, gamma, and delta hemolysin. Among them, alpha-toxin (Hla) is produced by most pathogenic strains and is considered a major virulence factor [15]. Several studies have reported the roles of $\alpha$-hemolysin in $S$. aureus pathogenesis, including cytokine release, cell signaling pathways that control cell proliferation, inflammatory responses, and cell-cell interactions, which result in mammary gland necrosis and higher mortality rates among the infected animals [16-19].

Panton-Valentine leukocidin toxin is a potent staphylococcal exotoxin that is activated by two secretory proteins of the F and S kinds [20]. It acts strongly on human polymorphonuclear cells and causes severe clinical manifestations, particularly with methicillinresistant $S$. aureus (MRSA), such as furunculosis, severe necrotizing pneumonia, and skin and tissue necrosis [21]. In patients with necrotizing pneumonia, it has been observed that the risk of death linked with $S$. aureus strains expressing the pvl gene is higher than that associated with PVL-negative bacteria [22].

An important public health issue concerning staphylococcal infections is the development of antibiotic resistance. Antibiotic resistance has emerged as a result of the widespread use of antimicrobials in food animal production, reducing the efficacy of various antibiotic classes for the treatment of infections in both humans and animals, particularly $\beta$-lactam antimicrobials, which are the most commonly used antibiotics in the treatment of animal diseases [23]. The use of these antibiotics in subtherapeutic doses in developing countries, including Egypt, for growth promotion and disease prevention raises the danger of new and more resistant bacteria emerging [24]. S. aureus resistance to $\beta$-lactam antibiotics is caused by two mechanisms: the production of penicillinase encoded by the blaZ gene [25], 
which is involved in the hydrolysis of $\beta$-lactam and inactivation of antibiotic, and an altered low-affinity penicillin-binding protein (PBP2-a) encoded by mecA, which accounts for methicillin-resistance [26-28].

Methicillin-resistant S. aureus (MRSA) with the mecA gene is resistant to a variety of antimicrobials [29]. Contamination of food by multidrug-resistance MRSA strains with a wide range of exotoxins, including enterotoxins and pol genes, confers life-threatening traits on MRSA, thereby making treatment complicated.

In Egypt, loose liquid milk sold at retail stores and by street vendors is preferred by consumers over bottled milk, which is thought to be made with powder milk, making it less appealing. There are several Egyptian reports regarding the prevalence and characterization of $S$. aureus possessing the pol gene in clinical isolates [30-33]. Despite its role in various severe clinical manifestations, genotypic and phenotypic analyses of PVL-positive S. aureus in retail food are still poorly performed in Egypt. Considering that raw milk is a vehicle for the transmission of numerous bacteria, including toxigenic and multidrug-resistant strains of human and animal origin, and represents a great risk for both animal and public health, this investigation aimed to find out the prevalence of PVL-positive S. aureus in retail milk and to characterize the obtained strains for their phenotypic and genotypic antimicrobial susceptibility and virulence traits to recognize the genetic background of food-related PVL-positive S. aureus in Egypt.

\section{Results}

\subsection{Prevalence and Molecular Characterization of PVL-Positive S. aureus}

Out of the investigated retail milk samples $(n=700), 288$ isolates were biochemically identified as $S$. aureus. The primer set used in this study for detection of the nuc gene (encodes a thermonuclease) yielded the expected 660-bp product for that gene and succeeded to amplify this product for all the tested isolates with an overall prevalence of $41.1 \%(288 / 700)$. Subsequently, S. aureus isolates were tested for the presence of the $\mathrm{pvl}$ gene. Overall, of the 288 S. aureus isolates, $113(39.2 \%, 113 / 288)$ tested positive for the $p v l$ gene (Figure 1). As a result, 113 bacterial isolates were subjected to genotypic and phenotypic analyses. PVL-positive $S$. aureus were then screened for the presence of the mecA gene, which was detected in 37 isolates (32.7\%), and they are classified as PVL-positive methicillin-resistant $S$. aureus (MRSA), while mecA-negative isolates were classified as PVL-positive methicillin-sensitive S. aureus (MSSA).

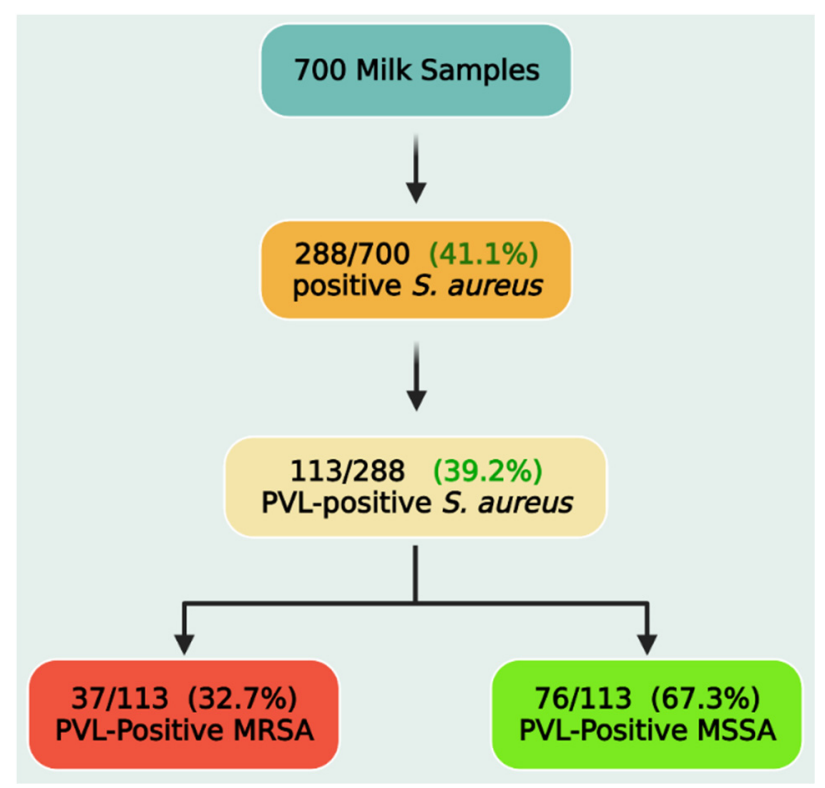

Figure 1. Prevalence of PVL-positive Staphylococcus aureus, methicillin-resistant (MRSA), and methicillin-sensitive Staphylococcus aureus (MSSA) strains. 


\subsection{Virulence Gene Profiles and Genotypic Profiles of $\beta$-Lactam Resistance}

PVL-positive $S$. aureus isolates were screened for the presence of toxin gene markers. In total, $50.4 \%$ (57/113) of PVL-positive S. aureus were found to harbor one or more SEs gene. In detail, the sea gene was the most common enterotoxin gene found among the tested isolates $(50 / 113 ; 44.2 \%)$, followed by the seb gene $(7 / 113 ; 6.2 \%)$ and the sec gene $(1 / 113$; $0.9 \%)$, while see, seg, sei, and selj were not detected in this study. In addition, the hla and tst genes were found in $54.9 \%(62 / 113)$ and $0.9 \%(1 / 113)$, respectively (Tables 1 and S1). PCR targeting the blaZ and mecA genes was used to test $S$. aureus strains for their genotypic resistance. Both the blaZ and mecA genes were recognized in $84.9 \%(96 / 113)$ and $32.7 \%$ (37/113) of the PVL-positive S. aureus isolates, respectively (Tables 1 and S1).

Table 1. Frequency distribution of antimicrobial resistance and virulence genes among the examined PVL-positive Staphylococcus aureus.

\begin{tabular}{cccc}
\hline \multirow{2}{*}{ Gene } & \multicolumn{3}{c}{ Frequency Distribution } \\
\cline { 2 - 4 } & PVL-Positive MRSA $(\boldsymbol{n}=\mathbf{3 7})$ & PVL-Positive MSSA $(\boldsymbol{n = 7 6 )}$ & Total PVL-Positive $\boldsymbol{S}$. aureus $(\boldsymbol{n}=\mathbf{1 1 3})$ \\
\hline mecA & $37(32.7 \%)$ & 0 & $37(32.7 \%)$ \\
blaZ & $32(28.3 \%)$ & $64(56.6 \%)$ & $96(84.9 \%)$ \\
tst & 0 & $1(0.9 \%)$ & $62(0.9 \%)$ \\
hla & $18(15.9 \%)$ & $44(38.9 \%)$ & $50(44.9 \%)$ \\
sea & $20(17.7 \%)$ & $30(26.6 \%)$ & $7(6.2 \%)$ \\
seb & $2(1.8 \%)$ & $5(4.4 \%)$ & $1(0.9 \%)$ \\
sec & 0 & $1(0.9 \%)$ & 0 \\
see & 0 & 0 & 0 \\
seg & 0 & 0 & 0 \\
sei & 0 & 0 & 0 \\
selj & 0 & 0 & $1(0.9 \%)$ \\
sea $/ \mathrm{seb}$ & 0 & $1(0.9 \%)$ & \\
\hline
\end{tabular}

\subsection{Antimicrobial Susceptibility Testing and Resistance Patterns of the PVL-Positive MRSA} and MSSA

The results of antimicrobial susceptibility testing of PVL-positive $S$. aureus isolates $(n=113)$ are listed in Table 2 . The PVL-positive $S$. aureus isolates were highly resistant to penicillin, ampicillin, and trimethoprim-sulfamethoxazole $(90.3 \%, 70.8 \%$, and 54.9\%, respectively), and moderately resistant to ciprofloxacin $(41.6 \%)$, clindamycin $(37.2 \%)$, and erythromycin (34.5\%). However, they were more sensitive to gentamicin $(79.6 \%)$ and chloramphenicol (85.8\%).

Table 2. Antimicrobial susceptibility of PVL-positive Staphylococcus aureus strains.

\begin{tabular}{|c|c|c|c|c|c|c|c|c|}
\hline \multirow[b]{2}{*}{ Antimicrobial Agent } & \multirow[b]{2}{*}{ Family } & \multirow[b]{2}{*}{ CPD } & \multicolumn{2}{|c|}{ PVL-Positive MRSA $(n=37)$} & \multicolumn{2}{|c|}{ PVL-Positive MSSA $(n=76)$} & \multicolumn{2}{|c|}{ PVL-Positive $S$. aureus $(n=113)$} \\
\hline & & & $\begin{array}{l}\text { Resistant } \\
\text { No (\%) }\end{array}$ & $\begin{array}{l}\text { Sensitive } \\
\text { No }(\%)\end{array}$ & $\begin{array}{l}\text { Resistant } \\
\text { No (\%) }\end{array}$ & $\begin{array}{c}\text { Sensitive } \\
\text { No (\%) }\end{array}$ & $\begin{array}{l}\text { Resistant } \\
\text { No (\%) }\end{array}$ & $\begin{array}{l}\text { Sensitive } \\
\text { No }(\%)\end{array}$ \\
\hline Penicillin (P) & $\beta$-lactam & $10 \mu \mathrm{g}$ & $37(32.7 \%)$ & 0 & $65(57.5 \%)$ & $11(9.7 \%)$ & $102(90.3 \%)$ & $11(9.7 \%)$ \\
\hline Ampicillin(AMP) & $\beta$-lactam & $10 \mu \mathrm{g}$ & $37(32.7 \%)$ & 0 & $43(38.05 \%)$ & $33(29.2 \%)$ & $80(70.8 \%)$ & $33(29.2 \%)$ \\
\hline Ciprofloxacin (CIP) & Fluoroquinolone & $5 \mu \mathrm{g}$ & $24(21.2 \%)$ & $13(11.5 \%)$ & $23(20.4 \%)$ & $53(46.9 \%)$ & $47(41.6 \%)$ & $66(58.4 \%)$ \\
\hline Chloramphenicol (C) & Phenicols & $30 \mu \mathrm{g}$ & $12(10.6 \%)$ & $25(22.1 \%)$ & $4(3.5 \%)$ & $72(63.7 \%)$ & $16(14.0 \%)$ & $97(85.8 \%)$ \\
\hline Clindamycin (DA) & Lincosamide & $2 \mu \mathrm{g}$ & $20(17.7 \%)$ & $17(15.04 \%)$ & $22(19.5 \%)$ & $54(47.8 \%)$ & $42(37.2 \%)$ & $71(62.8 \%)$ \\
\hline Erythromycin (E) & Macrolide & $15 \mu \mathrm{g}$ & $22(19.5 \%)$ & $15(13.3 \%)$ & $17(15.04 \%)$ & $59(52.2 \%)$ & $39(34.5 \%)$ & $74(65.5 \%)$ \\
\hline Gentamicin (CN) & Aminoglycoside & $10 \mu \mathrm{g}$ & $11(9.7 \%)$ & $26(23 \%)$ & $12(10.6 \%)$ & $64(56.6 \%)$ & $23(20.4 \%)$ & $90(79.6 \%)$ \\
\hline Tetracycline (TE) & Tetracycline & $30 \mu \mathrm{g}$ & $32(28.3 \%)$ & $5(4.4 \%)$ & $22(19.5 \%)$ & $54(36.3 \%)$ & $54(47.79 \%)$ & $59(40.7 \%)$ \\
\hline $\begin{array}{l}\text { Trimethoprim- } \\
\text { sulfamethoxazole (SXT) }\end{array}$ & Sulphonamide & $25 \mu \mathrm{g}$ & $35(31.0 \%)$ & $2(1.77 \%)$ & $27(23.9 \%)$ & $49(43.6 \%)$ & $62(54.9 \%)$ & $51(45.13 \%)$ \\
\hline
\end{tabular}

No: number.

A significantly higher resistance rate was displayed by the MRSA isolates (mecApositive) to all antimicrobials than the MSSA isolates (mecA-negative). All MRSA isolates $(100 \%)$ were resistant to penicillin and ampicillin, while $94.6 \%(35 / 37)$ were resistant to trimethoprim-sulfamethoxazole, $64.9 \%(24 / 37)$ to ciprofloxacin, 59.5\% (22/37) to erythromycin, $54.1 \%(20 / 37)$ to clindamycin, $86.5 \%(32 / 37)$ to tetracycline, $32.4 \%(12 / 37)$ 
to chloramphenicol, and $29.7 \%(11 / 37)$ to gentamycin. Interestingly, all MRSA isolates displayed MAR (resistance to three or more antimicrobial classes). Notably, $6.58 \%$ (5/76) of methicillin-sensitive S. aureus (MSSA) isolates were susceptible to all tested antimicrobials, $55.3 \%(42 / 76)$ of the 76 isolates were resistant to at least 1 antibiotic, and $38.2 \%(29 / 76)$ were resistant to 3 or more antimicrobial classes. The most prevalent antimicrobial-resistant profile of the MRSA isolates was P, AMP, CIP, DA, E, SXT, and TE. A higher MAR index was also noticed among MRSA isolates, which ranged between 0.44 and 1.0, while in MSSA it ranged between 0.00 and 1 (Tables 3 and 4, respectively).

Table 3. Antimicrobial resistance patterns and antibiotypes of PVL-positive MRSA strains.

\begin{tabular}{ccccc}
\hline Antibiotypes & Resistance Pattern & $\begin{array}{c}\text { Isolate No (\%) } \\
(\boldsymbol{n}=37)\end{array}$ & $\begin{array}{c}\text { MAR } \\
\text { Index }\end{array}$ & $\begin{array}{c}\text { MAR } \\
(\boldsymbol{n}=\mathbf{3 7})\end{array}$ \\
\hline I & P, AMP, C, and TE & $1(2.7 \%)$ & 0.44 & + \\
II & P, AMP, SXT, and TE & $1(2.7 \%)$ & 0.44 & + \\
III & P, AMP, CIP, and CN & $1(2.7 \%)$ & 0.44 & + \\
IV & P, AMP, C, SXT, and TE & $4(10.8 \%)$ & 0.56 & + \\
V & P, AMP, DA, E, and SXT & $1(2.7 \%)$ & 0.56 & + \\
VI & P, AMP, CIP, SXT, and TE & $5(13.5 \%)$ & 0.56 & + \\
VII & P, AMP, C, DA, SXT, and TE & $1(2.7 \%)$ & 0.67 & + \\
VIII & P, AMP, CIP, C, SXT, and TE & $1(2.7 \%)$ & 0.67 & + \\
IX & P, AMP, DA, E, SXT, and TE & $2(5.4 \%)$ & 0.67 & + \\
X & P, AMP, E, CN, SXT, and TE & $1(2.7 \%)$ & 0.67 & + \\
XI & P, AMP, CIP, DA, SXT, and TE & $1(2.7 \%)$ & 0.67 & + \\
XII & P, AMP, CIP, DA, E, SXT, and TE & $7(18.9 \%)$ & 0.78 & + \\
XIII & P, AMP, C, DA, E, SXT, and TE & $1(2.7 \%)$ & 0.78 & + \\
XIV & P, AMP, CIP, E, CN, SXT, and TE & $1(2.7 \%)$ & 0.78 & + \\
XV & P, AMP, CIP, DA, E, CN, and SXT & $3(8.1 \%)$ & 0.78 & + \\
XVI & P, AMP, DA, E, CN, SXT, and TE & $1(2.7 \%)$ & 0.78 & + \\
XVII & P, AMP, CIP, C, E, SXT, and TE & $1(2.7 \%)$ & 0.89 & + \\
XVIII & P, AMP, CIP, C, E, CN, SXT, and TE & $1(5.4 \%)$ & 0.89 & + \\
XIX & P, AMP, CIP, DA, E, CN, SXT, and TE & $1(2.7 \%)$ & 0.89 & + \\
XX & P, AMP, CIP, C, DA, E, CN, SXT, and TE & $2(5.4 \%)$ & 1 & + \\
\hline
\end{tabular}

Table 4. Antimicrobial resistance patterns and antibiotypes of PVL-positive MSSA strains.

\begin{tabular}{ccccc}
\hline Antibiotypes & Resistance Pattern & $\begin{array}{c}\text { Isolate No (\%) } \\
(\boldsymbol{n}=\mathbf{7 6})\end{array}$ & $\begin{array}{c}\text { MAR } \\
\text { Index }\end{array}$ & $\begin{array}{c}\text { MAR } \\
(\boldsymbol{n}=\mathbf{2 9})\end{array}$ \\
\hline I & 0 & $5(6.58 \%)$ & 0.00 & - \\
II & P & $26(34.2 \%)$ & 0.11 & - \\
III & CIP & $1(1.3 \%)$ & 0.11 & - \\
IV & AMP & $3(3.9 \%)$ & 0.11 & - \\
V & P and AMP & $6(7.9 \%)$ & 0.22 & - \\
VI & P and DA & $1(1.3 \%)$ & 0.22 & - \\
VII & AMP and DA & $2(2.6 \%)$ & 0.22 & - \\
VIII & P, AMP, and SXT & $1(1.3 \%)$ & 0.33 & - \\
IX & P, AMP, and CIP & $2(2.6 \%)$ & 0.33 & - \\
X & P, AMP, CIP, and DA & $2(2.6 \%)$ & 0.44 & + \\
XI & P, AMP, SXT, and TE & $4(5.2 \%)$ & 0.44 & + \\
XII & P, AMP, C, TE, and CIP & $1(1.3 \%)$ & 0.56 & + \\
XIII & P, AMP, CIP, CN, and SXT & $1(1.3 \%)$ & 0.56 & + \\
XIV & P, AMP, CIP, SXT, and TE & $1(1.3 \%)$ & 0.56 & + \\
XV & P, AMP, E, SXT, and TE & $1(1.3 \%)$ & 0.56 & + \\
XVI & P, AMP, CIP, C, and SXT & $1(1.3 \%)$ & 0.56 & + \\
XVII & P, AMP, CN, E, SXT, and TE & $1(1.3 \%)$ & 0.67 & + \\
XVIII & P, AMP, CIP, DA, E, and SXT & $3(3.9 \%)$ & 0.67 & + \\
XIX & P, AMP, CN, DA, SXT, and TE & $2(2.6 \%)$ & 0.67 & + \\
XX & P, AMP, CIP, DA, E, SXT, and TE & $2(2.6 \%)$ & 0.78 & + \\
XXI & P, AMP, DA, E, CN, SXT, and TE & $1(1.3 \%)$ & 0.78 & + \\
XXII & P, AMP, CIP, C, DA, E, SXT, and TE & $2(2.6 \%)$ & 0.89 & + \\
XXIII & P, AMP, CIP, DA, E, CN, SXT, and TE & $7(9.1 \%)$ & 0.89 & + \\
& & & + \\
\hline
\end{tabular}

2.4. Association of Resistance Phenotypes, Resistant Genes, and Virulence-Associated Genes in PVL-Positive S. aureus

The findings of correlation analysis revealed the existence of significant $(p<0.05)$ positive associations between pairs of antimicrobials belonging to different antimicrobial classes (Figures 2 and S1). Strong positive correlations $(r>0.6)$ were observed between the following antimicrobial pairs: TE and SXT ( $r=0.83)$, SXT and AMP $(r=0.71)$, DA and E $(r=0.67)$, SXT and E $(r=0.66)$, and TE and AMP $(r=0.61)$. Moderate $(r=0.4-0.6)$ and weak positive $(\mathrm{r}<0.4)$ correlations were also determined between pairs of the tested 
antimicrobials (Figure 2). Of the two resistance genes examined, the mec $A$ gene showed significant moderate correlations with SXT $(r=0.56)$, TE $(r=0.54)$, and AMP $(r=0.45)$ and weak positive correlations with $\mathrm{C}(r=0.39), \mathrm{E}(r=0.37), \mathrm{CIP}(r=0.33)$, and DA $(r=0.24)$. Concerning the virulence-resistance relationship, no significant correlations were found between the examined resistance and virulence genes.

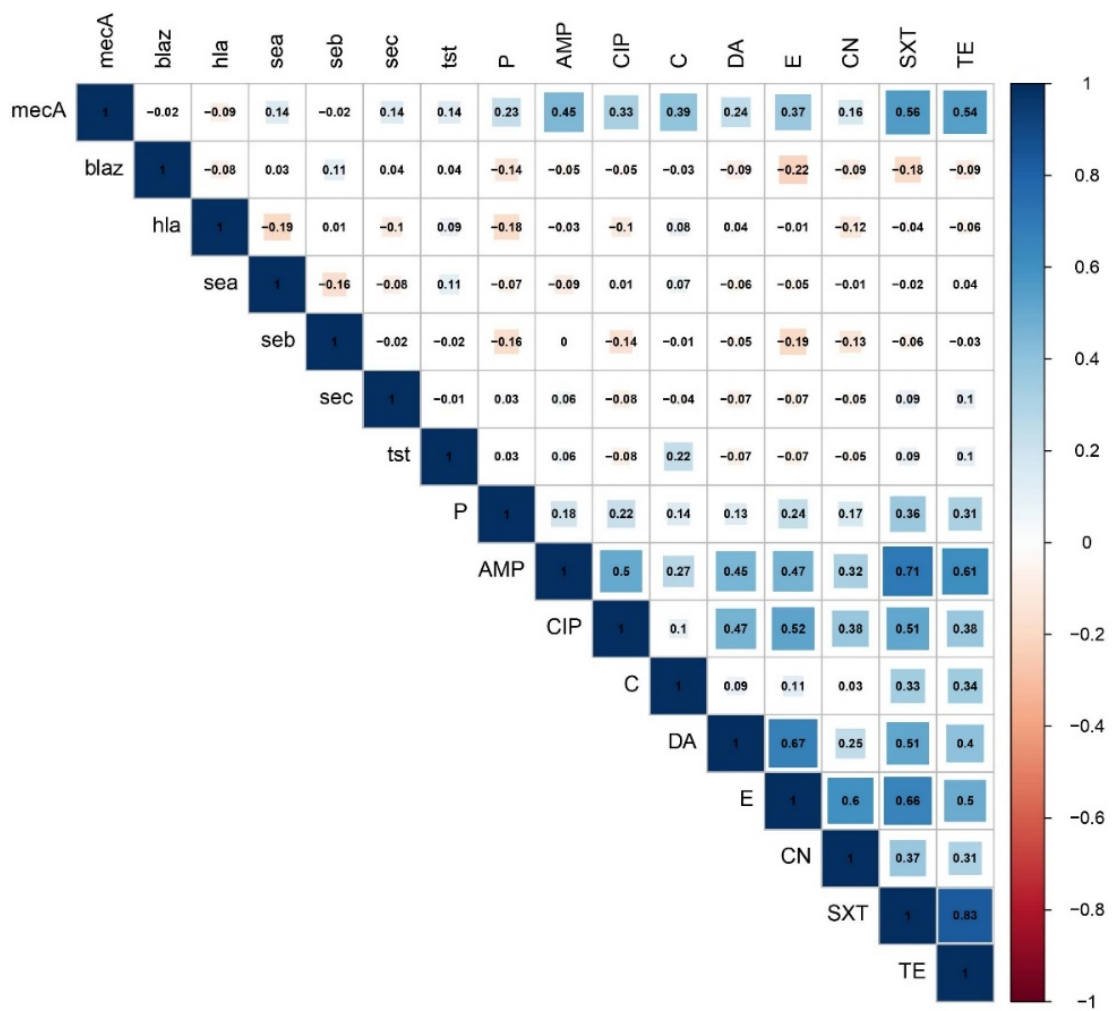

Figure 2. Association of resistance phenotypes, resistance genes, and virulence-associated genes in PVL-positive Staphylococcus aureus. The blue and orange colors of the boxes indicate positive and negative correlations, respectively. The strength of the colors corresponds to the numerical value of the correlation coefficient (r).

\section{Discussion}

Raw milk may pose a consumer risk, due to the possible presence of human pathogenic bacteria, such as S. aureus. S. aureus has been identified as a major cause of zoonotic disease, with the potential for MRSA transmission between animals and humans by direct contact, handling, and/or eating of S. aureus-infected animal products [34]. This investigation was conducted on a total of 700 raw milk samples, and a high prevalence $(41.1 \%)$ of $S$. aureus-contaminated raw cow's milk was found among the total examined samples. This finding is in agreement with those of other investigations performed in Egypt, which were ranged from 35.9 to $75 \%$ [11,35-39], in Turkey, where a 56\% prevalence rate of S. aureus was recovered out of 150 raw milk samples [40], and in China, where, out of 195 samples, 54 (27.7\%) were positive [41] and out of 144 samples, 62 (43.1\%) were positive for S. aureus [42].

In Egypt, the production and consumption of milk and dairy products are regulated by the law 132/1950, which consists of 14 articles. Moreover, the Egyptian general organization for standards and quality (EOS) issued a set of standards (154-1/2005) for milk and milk products (part1: raw milk) [43], available at: https://www.eos.org.eg/en/standard/2484, accessed on 20 December 2021. Generally, all dairy products (yogurt, cream, and butter) must be prepared from pasteurized milk, and all ingredients used in their manufacture must conform to the standard specifications of each of them. The Egyptian government allows the sale of raw (unpasteurized) milk in small shops and supermarkets. However, it must comply with the rules of the law and standards which set several standards regarding the dairy animals, milk and milk products, milk utensils, and milk handlers. Accordingly, 
the sale of milk is prohibited unless it is from healthy animals, clean and fresh, retains all its natural properties, free from impurities, dirt, and colored materials (Article 2). Further, milk must be free from several pathogens (specified in article 3) such as Brucella, Listeria monocytogenes, Mycobacterium tuberculosis, Bacillus anthracis, and Salmonella, while total Clostridium perfringens and Bacillus cereus must be $<1$ colony-forming unit (cfu)/mL), and total S. aureus count must be $<100 \mathrm{cfu} / \mathrm{mL}(\mathrm{ES}, 2005)$ [43]. The law also prohibits the sale or use of milk from some diseased animals (article 3), sets requirements for transportation means (article 6), milk containers (article 7), milk handlers, and street vendors allowed to sell milk (article 9).

Contamination of raw milk with $S$. aureus is usually related to mastitis or human carriers. The main sources of raw milk contamination include the milking process, environmental contamination with diseased animal manure, and inadequate handling during transportation to outlets and at milk collection facilities [44]. Therefore, raw milk collection, production, transportation, and sale should all be standardized. Simultaneously, appropriate professional training for workers is essential to reduce raw milk pollution caused by poor hygiene. PVL-positive $S$. aureus is a highly pathogenic $S$. aureus strain carrying PVL that affects humans and causes recurrent and potentially serious infections of the skin, ranging from isolated recurrent abscesses to extensive furunculosis and necrotizing pneumonia [45]. Delayed identification of PVL-positive S. aureus can lead to serious morbidity and mortality ranges from 40 to 60\% [46]. In this study, PVL-positive S. aureus strains were found in $39.2 \%$ of all S. aureus isolates tested. The detection of PVL-positive S. aureus from bovine milk with varying percentages has been reported in Korea [47], Minnesota (USA) [48], and Jabalpur (India) [49]. The frequency of PVL-positive S. aureus varies, depending on the sample type, geographic area [6], disparities in livestock breeding systems, animal species, milking methods, and hygienic conditions [50]. As a result, raw milk collection, production, transportation, and sale should all be standardized.

Panton-Valentine leukocidin is a human-associated leukocidin found mostly in S. aureus strains from humans [51,52]. The isolation of this gene from milk samples suggests that $S$. aureus is transmitted from human to cow $[14,53,54]$. The introduction of this bacterium from milkers' hands or teat cup liners to the udder may have contributed to poor hygiene during the milking process. As a result, because it is a food-related pathogen, it must be regarded a possible public health danger.

Staphylococcus aureus produces various virulence factors in addition to PVL. These factors are important for evading host defenses and causing microbial colonization of the animals' udders. Exotoxins produced by $S$. aureus can cause epidemics of staphylococcal food poisoning (SFP) from milk and dairy products intended for human consumption $[55,56]$. The pore-forming cytotoxin hemolysin, which is one of the key virulence factors of S. aureus [57], was found in 54.9\% of the PVL-positive S. aureus in this study. Similarly, Al-ashmawy et al. [36] found that the $\alpha$-hemolysin encoding gene (hla) was the most often discovered virulence gene from raw milk in Egypt (100\%) and in China (Ren et al. [58]; 96.9\%). It has been reported that staphylococcal enterotoxins (SEs) can retain their biological and immunological effects, even after pasteurization. The potential hazard posed by these strains was highlighted in several studies [51,59]. The classical enterotoxin genes were responsible for $90 \%$ of food poisoning occurrences [13]. In this investigation, at least one kind of enterotoxin gene was found in 57 (50.44\%) of PVL-positive S. aureus isolates. The sea gene was the most often encountered gene in this study, followed by the seb and sec genes. These findings are consistent with those of Chao et al. [60] and Peles et al. [61], who found a similar distribution of enterotoxin genes in S. aureus isolates in China and Hungary, respectively, while the sea, seb, and see genes were not identified. In addition, only 5 isolates exhibited the sec gene with a frequency of $6 \%$ in milk obtained from cows with subclinical mastitis in Wisconsin [62]. The sea gene is very resistant to pasteurization heat and maintains some biological activity at high temperatures [63]. It was reported as the most frequently identified gene in US food poisoning outbreaks [64]. 
Toxic shock syndrome toxin-1 is one of the most important virulence factors of S. aureus, causing multi-organ malfunction and acting as a superantigen, contributing to the pathogenic processes of bovine mastitis [65]. In our investigation, the tst gene, which is responsible for the production of TSST-1, was found infrequently $(0.9 \%)$. In much prior research, $t$ st was also found in a small percentage of $S$. aureus isolates from bovine milk [37,49,66,67], while Wang et al. [15] and Ren et al. [58] found a greater frequency of tst (94\% and $26.2 \%$, respectively).

Out of 113 PVL-positive $S$. aureus isolates, 32.7\% were confirmed as MRSA by the detection of mecA. The presence of MRSA in the examined PVL-positive isolates is a major public health concern due to the possibility of the transmission of multidrug-resistant MRSA strains through the food chain. A foodborne outbreak caused by MRSA has been reported previously [68]. PVL-positive MRSA was also detected in raw milk in Egypt in several previous studies [36,37,69-71], while, in other studies, none of the MRSA isolated from food harbored the pvl gene [66,71,72]. Acquisition of the pvl genes by MRSA is considered a problem for controlling infection by this clone. On the other hand, in this investigation, it was discovered that the presence of the mecA gene was not linked to the existence of enterotoxins in the tested isolates.

Antimicrobial agents, particularly $\beta$-lactams, are used worldwide to control S. aureus infection [73]. In rural areas, after injection of antibiotics to dairy animals, some farmers do not follow the guidelines regarding drug residues and milk their cows and sell the milk to the retail markets [74-77]. Unfortunately, no legislation in Egypt controls the use of antibiotics in dairy animals, according to WHO reports in 2013 [78] and 2017 [79] and Tartor et al. [80]. However, several organizations in Egypt make periodical inspection visits to dairy farms and plants to collect samples of the dairy products for analysis to assure that they conform to standards. However, this is mostly for large companies, and the control is weak over small unregistered and unlicensed plants. In the present study, penicillin had a resistance rate of $90.3 \%(102 / 113)$, which was the highest rate among the PVL-positive $S$. aureus isolates. These results agreed with many previous studies $[49,81]$. The blaZ gene, which is a common $\beta$-lactam resistant mechanism for $S$. aureus, was detected in $84.9 \%$ of the total examined strains. The high resistance against penicillin may be related to the frequent use of penicillin in the treatment of mastitis and the drying-off period. The phenotypic and genotypic differences in the results to penicillin agreed with Yang et al. [82] and Silva et al. [83], which may have contributed to the other resistance mechanisms or the expression of other genes. Additionally, some blaZ gene detection did not have a detectable phenotype, which may be related to the mechanisms of gene inactivation [84].

The high prevalence of MAR S. aureus and the presence of methicillin resistance among S. aureus are of both clinical and public health concerns. Interestingly, all MRSA isolates displayed MAR (resistance to three or more antimicrobials). While $6.58 \%$ of MSSA isolates were susceptible to all tested antimicrobials, 55.3\% were resistant to at least 1 antibiotic and $38.2 \%$ were multidrug-resistant to 3 or more antimicrobial classes. The presence of a high percentage of MAR $S$. aureus isolated from dairy cattle has been reported in Ethiopia $(98.3 \%)$, Italy (50\%), and South Africa (62\%) [85-87]. In the present study, penicillin resistance was common among MAR S. aureus isolates, which was also reported in several studies [88,89]. Interestingly, the values of the MAR index for all MRSA and most MSSA strains were higher than 0.2 , suggesting that the origin of these strains is from a high-risk source of contamination where antibiotics are frequently used. These findings underline the importance of adopting control measures against $S$. aureus in dairy farms to minimize the risks for both animal and public health.

\section{Conclusions}

The obtained results provide information regarding the prevalence of $S$. aureus from retail milk in Egypt. The isolated strains carried toxin genes that had a virulence potential and potential health risks which necessitate proper hygiene practices to prevent the spread of this clone through the food chain. In addition, it is necessary to raise awareness of small- 
holders of the necessity to keep milk refrigerated after milking and during transportation to the retail outlets to prevent food from being held at an unsafe temperature and avoid food poisoning by Staphylococcus. Our findings also revealed the existence of an alarming level of MRSA strains, and the development of multidrug resistance indicates an alarming situation; therefore, it is necessary to continuously monitor the use of antibiotics in dairy herds to minimize the risks for both animal and public health. Future studies should be conducted to investigate the risk involved in dairy cow colonization/infection.

\section{Materials and Methods}

\subsection{Sampling}

Unpasteurized raw cow's milk samples $(n=700)$ were collected from retail outlets located in Mansoura, Dakahliya, Egypt. Raw milk was obtained from retail markets which receive raw milk daily from smallholders who depend totally on hand milking. Fresh milk is transported to retail shops without refrigeration during transportation in small tanks. In retail shops, milk is dispensed in little plastic bags that are kept refrigerated until sold to the consumers. Samples were collected weekly from 20 retail markets from February 2019 to March 2020. The samples were stored in an insulated box containing ice packs (precooled to $-20{ }^{\circ} \mathrm{C}$ for $24 \mathrm{~h}$ ) and transported immediately to the laboratory of the Bacteriology, Mycology and Immunology department, Faculty of Veterinary Medicine, Mansoura University for examination within $3 \mathrm{~h}$.

\subsection{Bacterial Isolation}

Milk samples were incubated at $37^{\circ} \mathrm{C}$ for $24 \mathrm{~h}$ and then centrifuged at $3000 \mathrm{RPM}$ for $5 \mathrm{~min}$. The cream layer was discarded and the sediments were streaked on a mannitol salt agar (MSA) medium (Oxoid Ltd., Hampshire, England) and incubated for $24 \mathrm{~h}$ at $37^{\circ} \mathrm{C}$ to isolate $S$. aureus. The $S$. aureus were initially identified based on colony features (yellow colonies on MSA). One suspicious colony was picked up from MSA to be purified on trypticase soya agar (TSA, Oxoid Ltd., Hampshire, England), and kept at $4{ }^{\circ} \mathrm{C}$ for gram staining and biochemical assays (catalase, oxidase, and the tube coagulase test) [56]. The purified S. aureus colonies were preserved at $-80{ }^{\circ} \mathrm{C}$ in $30 \%$ glycerol for further molecular characterization.

\subsection{Genomic DNA Extraction and Molecular Characterization of PVL-Positive S. aureus}

Single colonies from an overnight culture were suspended in $1 \mathrm{~mL}$ of distilled water, homogenized by vortexing, and centrifuged for $1 \mathrm{~min}$ at 13,000 RPM. The bacteria were then resuspended in $200 \mu \mathrm{L}$ of distilled water, heated for $10 \mathrm{~min}$ at $100{ }^{\circ} \mathrm{C}$, and centrifuged again for $1 \mathrm{~min}$ at 13,000 RPM [14]. Thereafter, the obtained supernatant was stored at $-20^{\circ} \mathrm{C}$ for further molecular characterization. The species-specific nuc gene was used to confirm S. aureus by PCR (encoding for the $S$. aureus-specific thermonuclease) using the following primer sets: $n u c-F$ : (GCGATTGATGGTGATACGGTT) and $n u c-R$ : (AGCCAAGCCTTGACGAACTAA AGC) [90]. An initial denaturation at $94{ }^{\circ} \mathrm{C}$ for two min was applied, followed by 35 cycles of denaturation at $98^{\circ} \mathrm{C}$ for $10 \mathrm{~s}$, annealing at $58{ }^{\circ} \mathrm{C}$ for $30 \mathrm{~s}$, and extension at $68^{\circ} \mathrm{C}$ for $1 \mathrm{~min}$, followed by a final extension at $68^{\circ} \mathrm{C}$ for $7 \mathrm{~min}$. Confirmed S. aureus (nuc-positive) isolates were subjected to PCR for amplification of the pol gene, which was performed according to Lina et al. [46] using the primer sequences tabulated in Table 5 with the following cycling condition: $30 \mathrm{~s}$ of denaturation at $94{ }^{\circ} \mathrm{C}, 30 \mathrm{~s}$ of annealing at $55^{\circ} \mathrm{C}$, and $1 \mathrm{~min}$ of extension at $72{ }^{\circ} \mathrm{C}$ for 30 cycles. The PCR products were visualized by electrophoresis through $1 \%$ agarose stained by ethidium bromide.

\subsection{Antimicrobial Susceptibility Test}

According to the Clinical and Laboratory Standards Institute (CLSI), PVL-positive S. aureus isolates were tested for their antimicrobial susceptibility using the Kirby Bauer disk diffusion method on Muller Hinton agar plates (MH, Oxoid). The antimicrobials chosen are representative of those used in animal medicine. The following antibiotic disks 
were selected: ciprofloxacin (CIP; $5 \mu \mathrm{g})$, erythromycin $(\mathrm{E} ; 15 \mu \mathrm{g})$, gentamicin $(\mathrm{CN} ; 10 \mu \mathrm{g})$, penicillin (P; $10 \mathrm{IU})$, clindamycin (CL; $2 \mu \mathrm{g}$ ), ampicillin (AMP; $10 \mu \mathrm{g}$ ), chloramphenicol $(\mathrm{C} ; 30 \mu \mathrm{g})$, trimethoprim-sulfamethoxazole (SXT; $25 \mu \mathrm{g})$, and tetracycline (TE; $30 \mu \mathrm{g})$. The results were recorded and interpreted after $24 \mathrm{~h}$ of incubation at $37{ }^{\circ} \mathrm{C}$ following CLSI guidelines [91,92]. Multidrug resistance was mentioned as a single strain resistant to three or more antimicrobial classes [93]. A multiple antibiotic resistance (MAR) index was calculated by dividing the total number of antimicrobial resistances for each isolate by the total number of antimicrobials tested, according to Krumperman [94].

\subsection{Detection of Virulence-Associated Genes}

The PVL-positive $S$. aureus isolates were screened for the presence of several staphylococcal enterotoxin genes (SEs) by multiplex PCR. The detection of seven genes encoding enterotoxigenicity in PVL-positive S. aureus (sea, seb, sec, see, seg, sei, and selj) was performed using seven specific primer sets, according to Monday and Bohach [95] and Johnson et al. [96], while toxic shock syndrome toxin-1 (tst) and the hemolysin gene ( $h l a)$ were investigated as previously described by Sallam et al. [90].

\subsection{Genotypic Profile of $\beta$-Lactam Resistance}

The PVL-positive $S$. aureus isolates were subjected to PCR for the detection of $\beta$-lactam resistance genotypes by amplification of $m e c A$, which encodes the protein PBP2A, and blaZ, which encodes $\beta$-lactamases. For detection of both the blaZ and mec $A$ genes, PCRs were performed according to Oliveira et al. [97]. In brief, PCRs were performed in a 96-well 2720 thermal cycler (Applied Biosystems, Norwalk, CT) with a total volume of $25 \mu \mathrm{L}$ of reaction mix using the following cyclic conditions: initial denaturation at $95{ }^{\circ} \mathrm{C}$ for $5 \mathrm{~min}$, followed by 30 cycles of $95^{\circ} \mathrm{C}$ for $1 \mathrm{~min}, 54{ }^{\circ} \mathrm{C}$ for $1 \mathrm{~min}, 72^{\circ} \mathrm{C}$ for $1 \mathrm{~min}$, and a final extension at $72{ }^{\circ} \mathrm{C}$ for $7 \mathrm{~min}$. An aliquot of about $5 \mu \mathrm{L}$ of PCR product of each reaction was visualized by electrophoresis in $1 \%$ agarose stained by ethidium bromide.

Table 5. Sequences of primers and PCR conditions for the targeted genes examined in the present study.

\begin{tabular}{|c|c|c|c|}
\hline Target Gene & Primer Direction and Sequence & Amplicon Size (bp) & Reference \\
\hline nuc & $\begin{array}{c}\text { F: GTGCTGGCATATGTATGGCAATTG } \\
\text { R: CTGAATCAGCGTTGTCTTCGCTCCAA }\end{array}$ & 660 & [90] \\
\hline Pvl & $\begin{array}{c}\text { F: ATCATTAGGTAAAATGTCTGGACA } \\
\text { TGATCCA } \\
\text { R: GCATCAACTGTATTGGATAGCAAAAGC }\end{array}$ & 433 & [46] \\
\hline $\operatorname{mec} A$ & $\begin{array}{c}\text { F: TCCAGATTACAACTTCACCAGG } \\
\text { R: CCACTTCATATCTTGTAACG }\end{array}$ & 162 & [97] \\
\hline blaZ & $\begin{array}{l}\text { F: TACAACTGTAATATCGGAGGG } \\
\text { R: CATTACACTCTTGGCGGTTTC }\end{array}$ & 861 & [97] \\
\hline tst & $\begin{array}{c}\text { F: CGTAAGCCCTTTGTTGCTTG } \\
\text { R: CCACCCGTTTTATCGCTTGAAC }\end{array}$ & 543 & [90] \\
\hline hla & $\begin{array}{l}\text { F: CCGGTACTACAGATATTGGAAGC } \\
\text { R: GGTAATCATCACGAACTCGTTCG }\end{array}$ & 744 & [90] \\
\hline seb & $\begin{array}{l}\text { F: TCG CAT CAA ACT GAC AAA CG } \\
\text { R: GCA GGT ACT CTA TAA GTG CC }\end{array}$ & 478 & [96] \\
\hline sea & $\begin{array}{c}\text { F: GCA GGG AAC AGC TTT AGG C } \\
\text { R: GTT CTG TAG AAG TAT GAA ACA CG }\end{array}$ & 520 & [95] \\
\hline $\mathrm{sec}$ & $\begin{array}{l}\text { F: CTT GTA TGT ATG GAG GAA TAA CAA } \\
\text { R: TGC AGG CAT CAT ATC ATA CCA }\end{array}$ & 283 & [95] \\
\hline see & $\begin{array}{c}\text { F: TAC CAA TTA ACT TGT GGA TAG AC } \\
\text { R: CTC TTT GCA CCT TAC CGC }\end{array}$ & 170 & [95] \\
\hline seg & $\begin{array}{c}\text { F: CGT CTC CAC CTG TTG AAG G } \\
\text { R: CCA AGT GAT TGT CTA TTG TCG }\end{array}$ & 327 & [95] \\
\hline sei & $\begin{array}{c}\text { F: CAA CTC GAA TTT TCA ACA GGT AC } \\
\text { R: CAG GCA GTC CAT CTC CTG }\end{array}$ & 465 & [95] \\
\hline selj & $\begin{array}{l}\text { F: CAT CAG AAC TGT TGT TCC GCT AG } \\
\text { R: CTG AAT TTT ACC ATC AAA GGT AC }\end{array}$ & 142 & [95] \\
\hline
\end{tabular}




\subsection{Statistical Analysis}

The Pearson's correlation $(r)$ between the antimicrobial resistance phenotypes, resistance (mecA and blaZ), and virulence genes among the examined PVL-positive S. aureus was measured. For the resistance phenotype to each antimicrobial, the presence of a resistance and virulence gene received scores of 1 , whereas susceptibility to antimicrobials and the absence of a resistance and virulence gene received scores of 0 . The binary data $(0 / 1)$ were then uploaded into R software (version 3.6.1; https: / / www.r-project.org, accessed on 17 September 2021). Using the package "corrplot", the correlation at a significance of $p<0.05$ was calculated using the "cor" and "cor.mtest" functions, and the plot was generated using the "corrplot" function. Based on the value of $r$, the degree of correlation was considered strong, moderate, and weak if the $\mathrm{r}$ value was $>0.6,0.4-0.6$, and $<0.4$, respectively [98]. To visualize the overall distribution of the antimicrobial resistance phenotypes and virulence genes among the examined isolates, a heatmap with hierarchical clustering (Figure S2) based on the binary data $(0 / 1)$ of antimicrobial resistance and virulence genes was created using the package "pheatmap" in R software (version 217 3.4.2) [99].

Supplementary Materials: The following are available online at https:/ /www.mdpi.com/article/ 10.3390/toxins14020097/s1, Figure S1: Association between resistance phenotypes, resistant genes, and virulence-associated genes in Panton-Valentine Leukocidin (PVL)-positive Staphylococcus aureus showing a significant correlation. The blue and orange colors of boxes indicate positive and negative correlation, respectively. The strength of the colors corresponds to the numerical value of the correlation coefficient (r); Figure S2: A heatmap showing the distribution of resistance phenotypes and genotypes, and virulence-associated genes in Panton-Valentine Leukocidin (PVL)-positive Staphylococcus aureus; Table S1: Virulence gene profiles and genotypic profiles of $\beta$-lactam resistance among Panton-Valentine Leukocidin (PVL)-positive Staphylococcus aureus strains.

Author Contributions: Conceptualization, A.S., M.E. and A.A. (Amal Awad); methodology, A.S., R.R.S., A.M.M.F. and A.A. (Amal Awad); software, H.R., A.A. (Adel Alkhedaide), A.A. (Amira Abugomaa) and M.E.; validation, M.M.S. and A.A. (Amal Awad); formal analysis, H.R. and A.A. (Amira Abugomaa); investigation, A.S., R.R.S. and A.A. (Amal Awad); resources, A.S., R.R.S., A.M.M.F. and A.A. (Amal Awad); data curation, M.E., H.R. and A.A. (Amal Awad); writing-original draft preparation, A.S. and A.A. (Amal Awad); writing-review and editing, H.R., M.E. and A.A. (Amal Awad); supervision, M.E. and A.A. (Amal Awad); funding acquisition, A.A. (Adel Alkhedaide), M.M.S. and A.A. (Amal Awad). All authors have read and agreed to the published version of the manuscript.

Funding: This study was supported by the Taif University Researchers Supporting Project (TURSP2020/104), Taif University, Taif, Saudi Arabia.

Institutional Review Board Statement: The study was conducted according to the guidelines of the Declaration of Helsinki and approved by the Committee on the Ethics of Animal Experiments of the Faculty of Veterinary Medicine, Mansoura University (Permit numbers 08-24 on 17 September 2021).

Informed Consent Statement: Not applicable.

Data Availability Statement: The datasets generated during and/or analyzed during the current study are available from the corresponding author on reasonable request.

Acknowledgments: We appreciate and thank Taif University for the financial support for the Taif University Researchers Supporting Project (TURSP-2020/104), Taif University, Taif, Saudi Arabia.

Conflicts of Interest: The authors declare no conflict of interest. The funders had no role in the design of the study; in the collection, analyses, or interpretation of data; in the writing of the manuscript, or in the decision to publish the results. 


$\begin{array}{ll}\text { Abbreviations } \\ \text { PVL } & \text { Panton-Valentine leucocidin } \\ \text { MRSA } & \text { methicillin-resistant S. aureus } \\ \text { MSSA } & \text { methicillin-sensitive } \text { S. aureus } \\ \text { CLSI } & \text { Clinical and Laboratory Standards Institute } \\ \text { PCR } & \text { Polymerase chain reaction } \\ \text { TSB } & \text { Trypticase soy broth } \\ \text { MDR } & \text { Multidrug resistance } \\ \text { SEs } & \text { Staphylococcal enterotoxin genes } \\ \text { bp } & \text { Base pairs } \\ \text { TSST-1 } & \text { Toxic shock syndrome toxin-1 } \\ \text { VRSA } & \text { Vancomycin-resistant S. aureus strains } \\ \text { SFP } & \text { Staphylococcal food poisoning } \\ \text { CIP } & \text { Ciprofloxacin } \\ \text { E } & \text { Erythromycin } \\ \text { CN } & \text { Gentamicin } \\ \text { P } & \text { Penicillin } \\ \text { CL } & \text { Clindamycin } \\ \text { OX } & \text { Oxacillin } \\ \text { SAM } & \text { Ampicillin-sulbactam } \\ \text { C } & \text { Chloramphenicol } \\ \text { SXT } & \text { Trimethoprim-sulfamethoxazole } \\ \text { VA } & \text { Vancomycin Appendix A }\end{array}$

\section{References}

1. Dhanashekar, R.; Akkinepalli, S.; Nellutla, A. Milk-borne infections. An analysis of their potential effect on the milk industry. Germs 2012, 2, 101-109. [CrossRef] [PubMed]

2. Bennett, S.D.; Walsh, K.A.; Gould, L.H. Foodborne disease outbreaks caused by Bacillus cereus, Clostridium perfringens, and Staphylococcus aureus-United States, 1998-2008. Clin. Infect. Dis. 2013, 57, 425-433. [CrossRef] [PubMed]

3. Papadopoulos, P.; Papadopoulos, T.; Angelidis, A.S.; Boukouvala, E.; Zdragas, A.; Papa, A.; Hadjichristodoulou, C.; Sergelidis, D. Prevalence of Staphylococcus aureus and of methicillin-resistant S. aureus (MRSA) along the production chain of dairy products in north-western Greece. Food Microbiol. 2018, 69, 43-50. [CrossRef] [PubMed]

4. Turner, N.A.; Sharma-Kuinkel, B.K.; Maskarinec, S.A.; Eichenberger, E.M.; Shah, P.P.; Carugati, M.; Holland, T.L.; Fowler, V.G., Jr. Methicillin-resistant Staphylococcus aureus: An overview of basic and clinical research. Nat. Rev. Microbiol. 2019, 17, 203-218. [CrossRef] [PubMed]

5. Lejeune, J.T.; Rajala-Schultz, P.J. Food safety: Unpasteurized milk: A continued public health threat. Clin. Infect. Dis. 2009, 48, 93-100. [CrossRef] [PubMed]

6. Wu, S.; Zhang, F.; Huang, J.; Wu, Q.; Zhang, J.; Dai, J.; Zeng, H.; Yang, X.; Chen, M.; Pang, R.; et al. Phenotypic and genotypic characterization of PVL-positive Staphylococcus aureus isolated from retail foods in China. Int. J. Food Microbiol. 2019, 304, 119-126. [CrossRef]

7. Barrio, M.B.; Rainard, P.; Prevost, G. LukM/LukF'-PV is the most active Staphylococcus aureus leukotoxin on bovine neutrophils. Microbes. Infect. 2006, 8, 2068-2074. [CrossRef]

8. Rahimi, E.; Alian, F. Presence of enterotoxigenic Staphylococcus aureus in cow, camel, sheep, goat, and buffalo bulk tank milk. Vet. Arh. 2013, 83, 23-30.

9. Benic, M.; Habrun, B.; Kompes, G.; Mihaljevic, Z.; Cvetnic, Z.; Cergolj, M.; Macesic, N. Cell content in milk from cows with S. aureus intramammary infection. Vet. Arh. 2012, 82, 411-422.

10. Contreras, A.; Sierra, D.; Sanchez, A.; Corrales, J.C.; Marco, J.C.; Paape, M.J.; Gonzalo, C. Mastitis in small ruminants. Small Rumin. Res. 2007, 68, 145-153. [CrossRef]

11. Algammal, A.M.; Hetta, H.F.; Elkelish, A.; Alkhalifah, D.H.H.; Hozzein, W.N.; Batiha, G.E.; El Nahhas, N.; Mabrok, M.A Methicillin-Resistant Staphylococcus aureus (MRSA): One Health Perspective Approach to the Bacterium Epidemiology, Virulence Factors, Antibiotic-Resistance, and Zoonotic Impact. Infect. Drug Resist. 2020, 13, 3255-3265. [CrossRef] [PubMed]

12. Silva, S.D.S.P.D.; Cidral, T.A.; Soares, M.J.; de Melo, M.C. Enterotoxin-Encoding Genes in Staphylococcus spp. from Food Handlers in a University Restaurant. Foodborne Pathog. Dis. 2015, 12, 921-925. [CrossRef] [PubMed]

13. Tarekgne, E.K.; Skjerdal, T.; Skeie, S.; Rudi, K.; Porcellato, D.; Felix, B.; Narvhus, J.A. Enterotoxin Gene Profile and Molecular Characterization of Staphylococcus aureus Isolates from Bovine Bulk Milk and Milk Products of Tigray Region, Northern Ethiopia. J. Food Prot. 2016, 79, 1387-1395. [CrossRef] [PubMed] 
14. Mekonnen, S.A.; Lam, T.; Hoekstra, J.; Rutten, V.; Tessema, T.S.; Broens, E.M.; Riesebos, A.E.; Spaninks, M.P.; Koop, G. Characterization of Staphylococcus aureus isolated from milk samples of dairy cows in small holder farms of North-Western Ethiopia. BMC Vet. Res. 2018, 14, 246. [CrossRef] [PubMed]

15. Wang, D.; Zhang, L.; Zhou, X.; He, Y.; Yong, C.; Shen, M.; Szenci, O.; Han, B. Antimicrobial susceptibility, virulence genes, and randomly amplified polymorphic DNA analysis of Staphylococcus aureus recovered from bovine mastitis in Ningxia, China. J. Dairy Sci. 2016, 99, 9560-9569. [CrossRef] [PubMed]

16. Tam, K.; Torres, V.J. Staphylococcus aureus Secreted Toxins and Extracellular Enzymes. Microbiol. Spectr. 2019, 7, GPP3-0039-2018. [CrossRef]

17. Shambat, S.M.; Haggar, A.; Vandenesch, F.; Lina, G.; van Wamel, W.J.; Arakere, G.; Svensson, M.; Norrby-Teglund, A. Levels of alpha-toxin correlate with distinct phenotypic response profiles of blood mononuclear cells and with agr background of community-associated Staphylococcus aureus isolates. PLoS ONE 2014, 9, e106107. [CrossRef]

18. Maurer, K.; Reyes-Robles, T.; Alonzo, F., 3rd; Durbin, J.; Torres, V.J.; Cadwell, K. Autophagy mediates tolerance to Staphylococcus aureus alpha-toxin. Cell Host Microbe 2015, 17, 429-440. [CrossRef]

19. Popov, L.M.; Marceau, C.D.; Starkl, P.M.; Lumb, J.H.; Shah, J.; Guerrera, D.; Cooper, R.L.; Merakou, C.; Bouley, D.M.; Meng, W.; et al. The adherens junctions control susceptibility to Staphylococcus aureus alpha-toxin. Proc. Natl. Acad. Sci. USA 2015, 112, 14337-14342. [CrossRef]

20. Argudin, M.A.; Mendoza, M.C.; Rodicio, M.R. Food poisoning and Staphylococcus aureus enterotoxins. Toxins 2010, 2, 1751-1773. [CrossRef]

21. Rankin, S.; Roberts, S.; O’Shea, K.; Maloney, D.; Lorenzo, M.; Benson, C.E. Panton valentine leukocidin (PVL) toxin positive MRSA strains isolated from companion animals. Vet. Microbiol. 2005, 108, 145-148. [CrossRef] [PubMed]

22. Gillet, Y.; Issartel, B.; Vanhems, P.; Fournet, J.C.; Lina, G.; Bes, M.; Vandenesch, F.; Piemont, Y.; Brousse, N.; Floret, D.; et al. Association between Staphylococcus aureus strains carrying gene for Panton-Valentine leukocidin and highly lethal necrotising pneumonia in young immunocompetent patients. Lancet 2002, 359, 753-759. [CrossRef]

23. Pitkala, A.; Salmikivi, L.; Bredbacka, P.; Myllyniemi, A.L.; Koskinen, M.T. Comparison of tests for detection of beta-lactamaseproducing staphylococci. J. Clin. Microbiol. 2007, 45, 2031-2033. [CrossRef] [PubMed]

24. Santy-Tomlinson, J. Antimicrobial resistance stewardship: It's up to us all. Int. J. Orthop. Trauma Nurs. 2018, 28, 1-3. [CrossRef] [PubMed]

25. Zhang, H.Z.; Hackbarth, C.J.; Chansky, K.M.; Chambers, H.F. A proteolytic transmembrane signaling pathway and resistance to beta-lactams in staphylococci. Science 2001, 291, 1962-1965. [CrossRef]

26. Lowy, F.D. Antimicrobial resistance: The example of Staphylococcus aureus. J. Clin. Investig. 2003, 111, 1265-1273. [CrossRef]

27. Cikman, A.; Aydin, M.; Gulhan, B.; Karakecili, F.; Kurtoglu, M.G.; Yuksekkaya, S.; Parlak, M.; Gultepe, B.S.; Cicek, A.C.; Bilman, F.B.; et al. Absence of the mecC gene in methicillin-resistant Staphylococcus aureus isolated from various clinical samples: The first multi-centered study in Turkey. J. Infect. Public Health 2019, 12, 528-533. [CrossRef]

28. Perez, J.R.; Rosa, L.Z.; Sanchez, A.G.; Salcedo, J.H.d.M.; Rodriguez, J.M.A.; Horrillo, R.C.; Zurita, S.G.; Molino, M.G. Multiple Antimicrobial Resistance in Methicillin-Resistant Staphylococcus sciuri Group Isolates from Wild Ungulates in Spain. Antibiotics 2021, 10, 920. [CrossRef]

29. Morgan, M. Methicillin-resistant Staphylococcus aureus and animals: Zoonosis or humanosis? J. Antimicrob. Chemother. 2008, 62, 1181-1187. [CrossRef]

30. Hefzy, E.M.; Hassan, G.M.; El Reheem, F.A. Detection of Panton-Valentine Leukocidin-Positive Methicillin-Resistant Staphylococcus aureus Nasal Carriage among Egyptian Health Care Workers. Surg. Infect. 2016, 17, 369-375. [CrossRef]

31. Elgendy, S.G.; Hameed, W.A.; Hameed, M.R.A.; Hassan, A.T. Detection of Panton-Valentine Leukocidin Gene in Clinical Isolates of Staphylococci at Assiut University Hospitals. Egypt. J. Med. Microbiol. 2016, 25, 77-83. [CrossRef]

32. Khairalla, A.S.; Wasfi, R.; Ashour, H.M. Carriage frequency, phenotypic, and genotypic characteristics of methicillin-resistant Staphylococcus aureus isolated from dental health-care personnel, patients, and environment. Sci. Rep. 2017, 7, 7390. [CrossRef] [PubMed]

33. Ali, H.A.; El-Mahdy, R.H.; Gaballah, M.A. Community-acquired methicillin-resistant Staphylococcus aureus colonization in atopic dermatitis patients in Mansoura, Egypt. Biomed. Dermatol. 2019, 3, 2. [CrossRef]

34. Pereyra, E.A.; Picech, F.; Renna, M.S.; Baravalle, C.; Andreotti, C.S.; Russi, R.; Calvinho, L.F.; Diez, C.; Dallard, B.E. Detection of Staphylococcus aureus adhesion and biofilm-producing genes and their expression during internalization in bovine mammary epithelial cells. Vet. Microbiol. 2016, 183, 69-77. [CrossRef]

35. Ahmed, A.A.-H.; Maharik, N.M.S.; Valero, A.; Kamal, S.M. Incidence of enterotoxigenic Staphylococcus aureus in milk and Egyptian artisanal dairy products. Food Control 2019, 104, 20-27. [CrossRef]

36. Al-Ashmawy, M.A.; Sallam, K.I.; Abd-Elghany, S.M.; Elhadidy, M.; Tamura, T. Prevalence, Molecular Characterization, and Antimicrobial Susceptibility of Methicillin-Resistant Staphylococcus aureus Isolated from Milk and Dairy Products. Foodborne Pathog. Dis. 2016, 13, 156-162. [CrossRef]

37. Awad, A.; Ramadan, H.; Nasr, S.; Ateya, A.; Atwa, S. Genetic Characterization, Antimicrobial Resistance Patterns and Virulence Determinants of Staphylococcus aureus Isolated form Bovine Mastitis. Pak. J. Biol. Sci. 2017, 20, 298-305. [CrossRef] 
38. Abdeen, E.E.; Mousa, W.S.; Salam, S.Y.A.; Al-Maary, K.S.; Mubarak, A.S.; Moussa, I.M.; Hemeg, H.A.; Almuzaini, A.M.; Alajaji, A.I.; Alsubki, R.A.; et al. Antibiogram and phylogenetic diversity of enterotoxigenic Staphylococcus aureus strains from milk products and public health implications. Saudi J. Biol. Sci. 2020, 27, 1968-1974. [CrossRef]

39. Younis, G.; Sadat, A.; Maghawry, M. Characterization of Coa Gene and Antimicrobial Profiles of Staphylococcus Aureus Isolated from Bovine Clinical and Subclinical mastitis. Adv. Anim. Vet. Sci. 2018, 6, 161-168. [CrossRef]

40. Gundogan, N.; Avci, E. Occurrence and antibiotic resistance ofEscherichia coli, Staphylococcus aureusandBacillus cereusin raw milk and dairy products in Turkey. Int. J. Dairy Technol. 2014, 67, 562-569. [CrossRef]

41. Liu, H.; Li, S.; Meng, L.; Dong, L.; Zhao, S.; Lan, X.; Wang, J.; Zheng, N. Prevalence, antimicrobial susceptibility, and molecular characterization of Staphylococcus aureus isolated from dairy herds in northern China. J. Dairy Sci. 2017, 100, 8796-8803. [CrossRef] [PubMed]

42. Kou, X.; Cai, H.; Huang, S.; Ni, Y.; Luo, B.; Qian, H.; Ji, H.; Wang, X. Prevalence and Characteristics of Staphylococcus aureus Isolated from Retail Raw Milk in Northern Xinjiang, China. Front. Microbiol. 2021, 12, 705947. [CrossRef] [PubMed]

43. Egyptian Standards. Milk and Milk Products Part1: Raw Milk; Egyptian Organization for Standardization and Quality Control: Cairo, Egypt, 2005; pp. 1-154.

44. Addis, M.; Pal, M.; Kyule, M.N. Isolation and Identification of Staphylococcus Species from Raw Bovine Milk in Debre Zeit, Ethiopia. Vet. Res. 2011, 4, 45-49. [CrossRef]

45. Fogo, A.; Kemp, N.; Morris-Jones, R. PVL positive Staphylococcus aureus skin infections. BMJ 2011, 343, d5343. [CrossRef] [PubMed]

46. Lina, G.; Piemont, Y.; Godail-Gamot, F.; Bes, M.; Peter, M.O.; Gauduchon, V.; Vandenesch, F.; Etienne, J. Involvement of PantonValentine leukocidin-producing Staphylococcus aureus in primary skin infections and pneumonia. Clin. Infect. Dis. 1999, 29, 1128-1132. [CrossRef]

47. Kwon, N.H.; Park, K.T.; Moon, J.S.; Jung, W.K.; Kim, S.H.; Kim, J.M.; Hong, S.K.; Koo, H.C.; Joo, Y.S.; Park, Y.H. Staphylococcal cassette chromosome mec (SCCmec) characterization and molecular analysis for methicillin-resistant Staphylococcus aureus and novel SCCmec subtype IVg isolated from bovine milk in Korea. J. Antimicrob. Chemother. 2005, 56, 624-632. [CrossRef]

48. Haran, K.P.; Godden, S.M.; Boxrud, D.; Jawahir, S.; Bender, J.B.; Sreevatsan, S. Prevalence and characterization of Staphylococcus aureus, including methicillin-resistant Staphylococcus aureus, isolated from bulk tank milk from Minnesota dairy farms. J. Clin. Microbiol. 2012, 50, 688-695. [CrossRef]

49. Shrivastava, N.; Sharma, V.; Shrivastav, A.; Nayak, A.; Rai, A.K. Prevalence and characterization of Panton-Valentine leukocidinpositive Staphylococcus aureus in bovine milk in Jabalpur district of Madhya Pradesh, India. Vet. World. 2018, 11, 316-320. [CrossRef]

50. Umaru, G.A.; Kwaga, J.K.P.; Bello, M.; Raji, M.A.; Maitala, Y.S. Antibiotic resistance of Staphylococcus aureus isolated from fresh cow milk in settled Fulani herds in Kaduna State, Nigeria. Bull. Anim. Health Prod. Afr. 2016, 64, 173-182.

51. Dinges, M.M.; Orwin, P.M.; Schlievert, P.M. Exotoxins of Staphylococcus aureus. Clin. Microbiol. Rev. 2000, 13, 16-34. [CrossRef]

52. Vrieling, M.; Boerhout, E.M.; van Wigcheren, G.F.; Koymans, K.J.; Mols-Vorstermans, T.G.; de Haas, C.J.; Aerts, P.C.; Daemen, I.J.; van Kessel, K.P.; Koets, A.P.; et al. LukMF' is the major secreted leukocidin of bovine Staphylococcus aureus and is produced in vivo during bovine mastitis. Sci. Rep. 2016, 6, 37759. [CrossRef] [PubMed]

53. Schmidt, T.; Kock, M.M.; Ehlers, M.M. Molecular Characterization of Staphylococcus aureus Isolated from Bovine Mastitis and Close Human Contacts in South African Dairy Herds: Genetic Diversity and Inter-Species Host Transmission. Front. Microbiol. 2017, 8, 511. [CrossRef] [PubMed]

54. Crespo-Piazuelo, D.; Lawlor, P.G. Livestock-associated methicillin-resistant Staphylococcus aureus (LA-MRSA) prevalence in humans in close contact with animals and measures to reduce on-farm colonisation. Ir. Vet. J. 2021, 74, 21. [CrossRef] [PubMed]

55. Umeda, K.; Nakamura, H.; Yamamoto, K.; Nishina, N.; Yasufuku, K.; Hirai, Y.; Hirayama, T.; Goto, K.; Hase, A.; Ogasawara, J. Molecular and epidemiological characterization of staphylococcal foodborne outbreak of Staphylococcus aureus harboring seg, sei, sem, sen, seo, and selu genes without production of classical enterotoxins. Int. J. Food Microbiol. 2017, 256, 30-35. [CrossRef] [PubMed]

56. Wakabayashi, Y.; Umeda, K.; Yonogi, S.; Nakamura, H.; Yamamoto, K.; Kumeda, Y.; Kawatsu, K. Staphylococcal food poisoning caused by Staphylococcus argenteus harboring staphylococcal enterotoxin genes. Int. J. Food Microbiol. 2018, 265, 23-29. [CrossRef]

57. Chen, Y.; Yeh, A.J.; Cheung, G.Y.; Villaruz, A.E.; Tan, V.Y.; Joo, H.S.; Chatterjee, S.S.; Yu, Y.; Otto, M. Basis of virulence in a Panton-Valentine leukocidin-negative community-associated methicillin-resistant Staphylococcus aureus strain. J. Infect. Dis. 2015, 211, 472-480. [CrossRef]

58. Ren, Q.; Liao, G.; Wu, Z.; Lv, J.; Chen, W. Prevalence and characterization of Staphylococcus aureus isolates from subclinical bovine mastitis in southern Xinjiang, China. J. Dairy Sci. 2020, 103, 3368-3380. [CrossRef]

59. Le Loir, Y.; Baron, F.; Gautier, M. Staphylococcus aureus and food poisoning. Genet. Mol. Res. 2003, 2, 63-76.

60. Chao, G.; Bao, G.; Cao, Y.; Yan, W.; Wang, Y.; Zhang, X.; Zhou, L.; Wu, Y. Prevalence and diversity of enterotoxin genes with genetic background of Staphylococcus aureus isolates from different origins in China. Int. J. Food Microbiol. 2015, 211, 142-147. [CrossRef]

61. Peles, F.; Wagner, M.; Varga, L.; Hein, I.; Rieck, P.; Gutser, K.; Kereszturi, P.; Kardos, G.; Turcsanyi, I.; Beri, B.; et al. Characterization of Staphylococcus aureus strains isolated from bovine milk in Hungary. Int. J. Food Microbiol. 2007, 118, 186-193. [CrossRef] 
62. Oliveira, L.; Rodrigues, A.C.; Hulland, C.; Ruegg, P.L. Enterotoxin production, enterotoxin gene distribution, and genetic diversity of Staphylococcus aureus recovered from milk of cows with subclinical mastitis. Am. J. Vet. Res. 2011, 72, 1361-1368. [CrossRef] [PubMed]

63. Asao, T.; Kumeda, Y.; Kawai, T.; Shibata, T.; Oda, H.; Haruki, K.; Nakazawa, H.; Kozaki, S. An extensive outbreak of staphylococcal food poisoning due to low-fat milk in Japan: Estimation of enterotoxin A in the incriminated milk and powdered skim milk. Epidemiol. Infect. 2003, 130, 33-40. [CrossRef] [PubMed]

64. Omoe, K.; Ishikawa, M.; Shimoda, Y.; Hu, D.L.; Ueda, S.; Shinagawa, K. Detection of seg, seh, and sei genes in Staphylococcus aureus isolates and determination of the enterotoxin productivities of S. aureus isolates Harboring seg, seh, or sei genes. J. Clin. Microbiol. 2002, 40, 857-862. [CrossRef] [PubMed]

65. Perez, V.K.C.; Costa, G.M.D.; Guimaraes, A.S.; Heinemann, M.B.; Lage, A.P.; Dorneles, E.M.S. Relationship between virulence factors and antimicrobial resistance in Staphylococcus aureus from bovine mastitis. J. Glob. Antimicrob. Resist. 2020, 22, 792-802 [CrossRef]

66. Fessler, A.; Scott, C.; Kadlec, K.; Ehricht, R.; Monecke, S.; Schwarz, S. Characterization of methicillin-resistant Staphylococcus aureus ST398 from cases of bovine mastitis. J. Antimicrob. Chemother. 2010, 65, 619-625. [CrossRef]

67. Yang, F.L.; Li, X.S.; Liang, X.W.; Zhang, X.F.; Qin, G.S.; Yang, B.Z. Detection of virulence-associated genes in Staphylococcus aureus isolated from bovine clinical mastitis milk samples in Guangxi. Trop. Anim. Health Prod. 2012, 44, 1821-1826. [CrossRef]

68. Jones, T.F.; Kellum, M.E.; Porter, S.S.; Bell, M.; Schaffner, W. An outbreak of community-acquired foodborne illness caused by methicillin-resistant Staphylococcus aureus. Emerg. Infect. Dis. 2002, 8, 82-84. [CrossRef]

69. Kamal, R.M.; Bayoumi, M.A.; El Aal, S.F.A. MRSA detection in raw milk, some dairy products and hands of dairy workers in Egypt, a mini-survey. Food Control 2013, 33, 49-53. [CrossRef]

70. Algammal, A.M.; Enany, M.E.; El-Tarabili, R.M.; Ghobashy, M.O.I.; Helmy, Y.A. Prevalence, Antimicrobial Resistance Profiles, Virulence and Enterotoxins-Determinant Genes of MRSA Isolated from Subclinical Bovine Mastitis in Egypt. Pathogens 2020, 9, 362. [CrossRef]

71. Turkyilmaz, S.; Tekbiyik, S.; Oryasin, E.; Bozdogan, B. Molecular epidemiology and antimicrobial resistance mechanisms of methicillin-resistant Staphylococcus aureus isolated from bovine milk. Zoonoses Public Health 2010, 57, 197-203. [CrossRef]

72. Rhee, C.H.; Woo, G.J. Emergence and characterization of foodborne methicillin-resistant Staphylococcus aureus in Korea. J. Food Prot. 2010, 73, 2285-2290. [CrossRef] [PubMed]

73. Spohr, M.; Rau, J.; Friedrich, A.; Klittich, G.; Fetsch, A.; Guerra, B.; Hammerl, J.A.; Tenhagen, B.A. Methicillin-resistant Staphylococcus aureus (MRSA) in three dairy herds in southwest Germany. Zoonoses Public Health 2011, 58, 252-261. [CrossRef] [PubMed]

74. Hussein, S.A.E.-M.; Ahlam, A.E.-L.; Mahmoud, N.E. Antibiotics Residues of Some Famous Antibiotics in Raw Milk of Different Species Sold at Local Markets. Alex. J. Vet. Sci. 2020, 64, 72.

75. Kumar, N.; Sharma, G.; Leahy, E.; Shome, B.R.; Bandyopadhyay, S.; Deka, R.P.; Shome, R.; Dey, T.K.; Lindahl, J.F. Understanding Antibiotic Usage on Small-Scale Dairy Farms in the Indian States of Assam and Haryana Using a Mixed-Methods ApproachOutcomes and Challenges. Antibiotics 2021, 10, 1124. [CrossRef] [PubMed]

76. Redding, L.E.; Cubas-Delgado, F.; Sammel, M.D.; Smith, G.; Galligan, D.T.; Levy, M.Z.; Hennessy, S. Antibiotic residues in milk from small dairy farms in rural Peru. Food Addit. Contam. Part A 2014, 31, 1001-1008. [CrossRef]

77. Orwa, J.D.; Matofari, J.W.; Muliro, P.S.; Lamuka, P. Assessment of sulphonamides and tetracyclines antibiotic residue contaminants in rural and peri urban dairy value chains in Kenya. Int. J. Food Contam. 2017, 4, 5. [CrossRef]

78. World Health Organization. Regional Office for the Eastern Mediterranean. Report on the Consultative Meeting on Antimicrobial Resistance for Countries in the Eastern Mediterranean Region: From Policies to Action; Sharm El Sheikh, Egypt, 2013. Available online: http:/ / apps.who.int/iris/handle/10665/11 (accessed on 20 December 2021).

79. World Health Organization. Antimicrobial Resistance for Countries in the Eastern Mediterranean Region. 2017. Available online: https://apps.who.int/iris/handle/10665/259051 (accessed on 20 December 2021).

80. Tartor, Y.H.; Gharieb, R.M.A.; El-Aziz, N.K.A.; El Damaty, H.M.; Enany, S.; Khalifa, E.; Attia, A.S.A.; Abdellatif, S.S.; Ramadan, H Virulence Determinants and Plasmid-Mediated Colistin Resistance mcr Genes in Gram-Negative Bacteria Isolated From Bovine Milk. Front. Cell. Infect. Microbiol. 2021, 11, 761417. [CrossRef]

81. Mechesso, A.F.; Kim, S.J.; Park, H.S.; Choi, J.H.; Song, H.J.; Kim, M.H.; Lim, S.K.; Yoon, S.S.; Moon, D.C. Short communication: First detection of Panton-Valentine leukocidin-positive methicillin-resistant Staphylococcus aureus ST30 in raw milk taken from dairy cows with mastitis in South Korea. J. Dairy Sci. 2021, 104, 969-976. [CrossRef]

82. Yang, F.; Wang, Q.; Wang, X.; Wang, L.; Xiao, M.; Li, X.; Zhang, S.; Li, H.; Luo, J. Prevalence of blaZ gene and other virulence genes in penicillin-resistantStaphylococcus aureus isolated from bovine mastitis cases in Gansu, China. Turk. J. Vet. Anim. Sci. 2015, 39, 634-636. [CrossRef]

83. Silva, A.T.F.; da Silva, J.G.; Aragao, B.B.; Peixoto, R.M.; Mota, R.A. Occurrence of beta-lactam-resistant Staphylococcus aureus in milk from primiparous dairy cows in the northeastern region of Brazil. Trop. Anim. Health Prod. 2020, 52, 2303-2307. [CrossRef]

84. Hammad, A.M.; Shimamoto, T.; Shimamoto, T. Genetic characterization of antibiotic resistance and virulence factors in Enterococcus spp. from Japanese retail ready-to-eat raw fish. Food Microbiol. 2014, 38, 62-66. [CrossRef] [PubMed]

85. Fikru, G. Staphylococcus: Epidemiology and its Drug Resistance in Cattle, Food Chains and Humans in Central Ethiopia. Master's Thesis, Addis Ababa University, Bishoftu, Ethiopia, 2014. 
86. Normanno, G.; Corrente, M.; La Salandra, G.; Dambrosio, A.; Quaglia, N.C.; Parisi, A.; Greco, G.; Bellacicco, A.L.; Virgilio, S.; Celano, G.V. Methicillin-resistant Staphylococcus aureus (MRSA) in foods of animal origin product in Italy. Int. J. Food Microbiol. 2007, 117, 219-222. [CrossRef] [PubMed]

87. Mphahlele, M.P.; Oguttu, J.W.; Petzer, I.M.; Qekwana, D.N. Prevalence and antimicrobial drug resistance of Staphylococcus aureus isolated from cow milk samples. Vet. World 2020, 13, 2736-2742. [CrossRef] [PubMed]

88. Mekuria, A.; Asrat, D.; Woldeamanuel, Y.; Tefera, G. Identification and antimicrobial susceptibility of Staphylococcus aureus isolated from milk samples of dairy cows and nasal swabs of farm workers in selected dairy farms around Addis Ababa, Ethiopia. Afr. J. Microbiol. Res. 2013, 7, 3501-3510.

89. Sharma, D.; Sharma, P.K.; Malik, A. Prevalence and Antimicrobial Susceptibility of Drug Resistant Staphylococcus aureus in Raw Milk of Dairy Cattle. Int. Res. J. Microbiol. 2011, 2, 466-470.

90. Sallam, K.I.; Abd-Elghany, S.M.; Elhadidy, M.; Tamura, T. Molecular Characterization and Antimicrobial Resistance Profile of Methicillin-Resistant Staphylococcus aureus in Retail Chicken. J. Food Prot. 2015, 78, 1879-1884. [CrossRef]

91. Weinstein, M.P.; Lewis, J.S., 2nd. The Clinical and Laboratory Standards Institute Subcommittee on Antimicrobial Susceptibility Testing: Background, Organization, Functions, and Processes. J. Clin. Microbiol. 2020, 58, e01864-19. [CrossRef]

92. Wayne, P.A. Clinical and Laboratory Standards Institute (CLSI), Performance Standards for Antimicrobial Susceptibility Testing. Inform. Suppl. 2011, 31, 100-121.

93. Waters, A.E.; Contente-Cuomo, T.; Buchhagen, J.; Liu, C.M.; Watson, L.; Pearce, K.; Foster, J.T.; Bowers, J.; Driebe, E.M.; Engelthaler, D.M.; et al. Multidrug-Resistant Staphylococcus aureus in US Meat and Poultry. Clin. Infect. Dis. 2011, 52, 1227-1230. [CrossRef]

94. Krumperman, P.H. Multiple antibiotic resistance indexing of Escherichia coli to identify high-risk sources of fecal contamination of foods. Appl. Environ. Microbiol. 1983, 46, 165-170. [CrossRef]

95. Monday, S.R.; Bohach, G.A. Use of multiplex PCR to detect classical and newly described pyrogenic toxin genes in staphylococcal isolates. J. Clin. Microbiol. 1999, 37, 3411-3414. [CrossRef] [PubMed]

96. Johnson, W.M.; Tyler, S.D.; Ewan, E.P.; Ashton, F.E.; Pollard, D.R.; Rozee, K.R. Detection of genes for enterotoxins, exfoliative toxins, and toxic shock syndrome toxin 1 in Staphylococcus aureus by the polymerase chain reaction. J. Clin. Microbiol. 1991, 29, 426-430. [CrossRef] [PubMed]

97. Oliveira, C.J.; Tiao, N.; de Sousa, F.G.; de Moura, J.F.; Filho, L.S.; Gebreyes, W.A. Methicillin-Resistant Staphylococcus aureus from Brazilian Dairy Farms and Identification of Novel Sequence Types. Zoonoses Public Health 2016, 63, 97-105. [CrossRef]

98. Jiang, H.; Yu, T.; Yang, Y.; Yu, S.; Wu, J.; Lin, R.; Li, Y.; Fang, J.; Zhu, C. Co-occurrence of Antibiotic and Heavy Metal Resistance and Sequence Type Diversity of Vibrio parahaemolyticus Isolated from Penaeus vannamei at Freshwater Farms, Seawater Farms, and Markets in Zhejiang Province, China. Front. Microbiol. 2020, 11, 1294. [CrossRef]

99. Kolde, R. Package 'pheatmap'. R Package 2015, 1, 790. 